\title{
Recognition of Morganella Subspecies, with Proposal of Morganella morganii subsp. morganii subsp. nov. and Morganella morganii subsp. sibonii subsp. nov.
}

\author{
KJELD TRUBERG JENSEN, ${ }^{1 *}$ WILHELM FREDERIKSEN, ${ }^{1}$ FRANCES W. HICKMAN-BRENNER, ${ }^{2}$ \\ ARNOLD G. STEIGERWALT ${ }^{3}$ CONRADINE F. RIDDLE, ${ }^{4}$ AND DON J. BRENNER ${ }^{3}$ \\ Department of Clinical Microbiology, Statens Seruminstitut, Copenhagen, Denmark, ${ }^{1}$ and Enteric Diseases \\ Branch ${ }^{2}$ and Meningitis and Special Pathogens Branch, ${ }^{3}$ Division of Bacterial and Mycotic Diseases, and \\ Nosocomial Infections Laboratory Branch, ${ }^{4}$ Hospital Infections Program, National Center for Infectious \\ Diseases, Centers for Disease Control, Atlanta, Georgia 30333
}

\begin{abstract}
The genus name Morganella was established within the family Enterobacteriaceae in 1978. Morganella morganii is the only species described thus far within this genus, and the name $M$. morganii has been accepted by usage in the scientific community for strains previously known as Proteus morganii. M. morganii isolates differ in their abilities to ferment trehalose and exhibit variable lysine and ornithine decarboxylase patterns, emphasizing the phenotypic heterogeneity within this species. Previous genetic studies failed to reveal separate entities within the genus Morganella. We observed some trehalose-fermenting strains with different lysine and ornithine decarboxylase patterns. Two strains were lysine and ornithine positive, 3 were lysine positive and ornithine negative, and 29 were lysine negative and ornithine positive. These strains and 25 non-trehalosefermenting strains with different lysine and ornithine decarboxylase patterns were investigated. DNA-DNA hybridization studies and phenotypic characterizations revealed that $M$. morganii can be separated into three DNA relatedness groups and seven biogroups. Strains from DNA relatedness group 1 were trehalose negative, and strains from DNA relatedness groups 2 and 3 were trehalose positive. One biogroup from DNA relatedness group 2 was phenotypically indistinguishable from DNA relatedness group 3 . On the basis of these studies, we propose that $M$. morganii be subdivided into $M$. morganii subsp. morganii (type strain ATCC 25830) containing biogroups A, B, C, and D (DNA relatedness group 1) and $M$. morganii subsp. sibonii (type strain 8103-85; =ATCC 49948) containing biogroups E, F, and G (DNA relatedness groups 2 and 3).
\end{abstract}

On the basis of genetic studies performed by Brenner et al. in 1978, strains previously known as Proteus morganii were placed in a new genus, Morganella, and designated Morganella morganii (1). The name $M$. morganii is included in the "Approved Lists of Bacterial Names" (18) and has been accepted by usage in the scientific community. The genus name Morganella was first proposed by MacDonald Fulton in 1943 (6). M. morganii is the only species.

However, prior to the transfer of $P$. morganii to the genus Morganella, the homogeneity of this group of organisms was questioned by Siboni, who showed that $M$. morganii could be divided into two groups based on trehalose fermentation, resistance to tetracycline, and flagellar wavelength (16). Recently, the association between trehalose fermentation and tetracycline resistance in $M$. morganii has been observed by others (15). Additional studies by Hickman et al. also called attention to diversity among strains of $M$. morganii (9). They described two groups of $M$. morganii with atypical lysine and ornithine decarboxylase reactions. One group was lysine positive, and another group was ornithine negative. The two groups were shown to be closely related to $M$. morganii ${ }^{\mathrm{T}}$ by DNA-DNA hybridization studies. Nonmotile members of the lysine-positive group were later designated $M$. morganii biogroup 1 by Farmer et al. (5).

Decarboxylation of lysine has been assumed to be associated with the presence of a large plasmid in some strains of $M$. morganii, and the value of using this characteristic for biogrouping has been questioned (3).

We observed three strains that were lysine positive,

\footnotetext{
* Corresponding author.
}

ornithine negative, and trehalose fermenting and two strains that were lysine positive, ornithine positive, and trehalose fermenting but otherwise resembled $M$. morganii biochemically. These observations prompted further investigations, including DNA-DNA hybridization. The results of these investigations showed that $M$. morganii can be divided into two subspecies and seven biogroups.

\section{MATERIALS AND METHODS}

Bacterial strains. The strains included in the study, their origins, and their sources together with some phenotypic characteristics are shown in Table 1 . There are seven phenotypic groups. Group A (three isolates) includes the type strain $M$. morganii ATCC 25830 . Strain $4567-84^{\mathrm{T}}$ is a culture of ATCC $25830^{\mathrm{T}}$ maintained at the Centers for Disease Control (CDC) since 1973. Group B (15 strains) belongs to the lysine-positive biogroup of Hickman et al. (9). Group C (four strains) and group D (three strains) consist of non-trehalose-fermenting strains with atypical decarboxylase reactions. Group $E$ (two strains) and group $F$ (four strains, six isolates) consist of trehalose-fermenting strains with atypical decarboxylase reactions. Group G-1 (8 strains from the CDC, Atlanta, Ga., and strain 20980/68 from K. Siboni, Odense, Denmark) and group G-2 (20 strains from K. Siboni, Odense, Denmark) are groups of trehalose-fermenting strains that resemble group A with respect to decarboxylase reactions. The strains received from Siboni have been studied previously $(16,17)$.

Identification. The biochemical test methods used have been described elsewhere $(8,9)$. The strains received from Siboni were reexamined biochemically. 
TABLE 1. Sources, origins, and phenotypic characteristics of strains studied ${ }^{a}$

\begin{tabular}{|c|c|c|c|c|c|c|c|c|c|}
\hline Strain & Biogroup & Source & Origin & Lys & Orn & Tre & Gly & Tet & Mot \\
\hline $25830^{\mathrm{T}}$ & A & ATCC & Stool & 0 & + & 0 & $(+)$ & $\mathbf{S}$ & $(+)$ \\
\hline $4567-84^{\mathrm{T}}$ & & CDC & Stool & 0 & + & 0 & $(+)$ & $\mathbf{S}$ & $(+)$ \\
\hline $1881-73$ & & CDC & Stool & 0 & + & 0 & + & $\mathbf{S}$ & 0 \\
\hline $1939-76$ & B & $\mathrm{CDC}$ & Urine & + & + & 0 & + & $\mathbf{S}$ & 0 \\
\hline $1274-75$ & & $\mathrm{CDC}$ & Neck abscess & + & + & 0 & + & $\mathbf{S}$ & 0 \\
\hline $2325-70$ & & CDC & Stool & + & + & 0 & 0 & $\mathbf{S}$ & + \\
\hline $1143-76$ & & $\mathrm{CDC}$ & Stool & + & + & 0 & $(+)$ & $\mathbf{S}$ & + \\
\hline $1072-76$ & & CDC & Stool & + & + & 0 & + & $\mathrm{S}$ & 0 \\
\hline $392-75$ & & $\mathrm{CDC}$ & Gastric ulcer & + & + & 0 & + & $\mathbf{S}$ & 0 \\
\hline $3528-75$ & & $\mathrm{CDC}$ & Urine & + & + & 0 & + & I & 0 \\
\hline $632-76$ & & $\mathrm{CDC}$ & Sputum & + & + & 0 & + & I & 0 \\
\hline 1753-71 & & CDC & Wound & + & + & 0 & 0 & $\mathbf{S}$ & + \\
\hline $4510-74$ & & CDC & Sputum & + & + & 0 & + & $S$ & 0 \\
\hline $420-75$ & & CDC & Wound & + & + & 0 & + & $\mathbf{S}$ & 0 \\
\hline $2432-75$ & & $\mathrm{CDC}$ & Stool & + & + & 0 & + & $\mathbf{S}$ & 0 \\
\hline $1126-76$ & & $\mathrm{CDC}$ & Tracheostomy wound & + & + & 0 & + & $\mathbf{S}$ & 0 \\
\hline $3544-74$ & & $\mathrm{CDC}$ & Groin wound & + & + & 0 & + & $\mathbf{S}$ & 0 \\
\hline $3566-75$ & & CDC & Eye & + & + & 0 & + & $\mathbf{S}$ & 0 \\
\hline $1427-73$ & C & $\mathrm{CDC}$ & Sputum & 0 & 0 & 0 & + & $\mathbf{S}$ & 0 \\
\hline $4564-73$ & & $\mathrm{CDC}$ & Urine & 0 & 0 & 0 & $(+)$ & $\mathbf{R}$ & 0 \\
\hline $4195-69$ & & CDC & Stool & 0 & 0 & 0 & $(+)$ & $\mathbf{R}$ & + \\
\hline $3483-75$ & & $\mathrm{CDC}$ & Bile & 0 & 0 & 0 & + & $\mathbf{R}$ & + \\
\hline $2866-78$ & D & $\mathrm{CDC}$ & Sputum & + & 0 & 0 & + & I & 0 \\
\hline $728-77$ & & CDC & Tracheal secretion & + & 0 & 0 & + & $\mathbf{S}$ & 0 \\
\hline $1584-68$ & & $\mathrm{CDC}$ & Wound & + & 0 & 0 & + & $\mathbf{S}$ & 0 \\
\hline AB 2429 & E & SSI & Wound & + & + & + & 0 & $\mathbf{R}$ & + \\
\hline AB 2174 & & SSI & Wound & + & + & + & 0 & $\mathbf{R}$ & + \\
\hline $13-82$ & $\mathrm{~F}$ & von Graevenitz ${ }^{b}$ & Unknown & + & 0 & + & $(+)$ & $\mathbf{R}$ & + \\
\hline $13-82$ (c2) (AB 2304) & & $\mathrm{CDC}$ & Single colony from $13-82$ & 0 & 0 & + & 0 & $\mathrm{R}$ & + \\
\hline $13-82$ (c3) (AB 2305) & & $\mathrm{CDC}$ & Single colony from $13-82$ & + & 0 & + & 0 & $\mathbf{R}$ & $t^{c}$ \\
\hline $8103-85$ (AB 2048) & & SSI & Sputum & + & 0 & + & $(+)$ & $\mathbf{R}$ & + \\
\hline $8104-85$ (AB 2230) & & SSI & Anus & + & 0 & + & $(+)$ & $\mathbf{R}$ & + \\
\hline $2134-79$ & & $\mathrm{CDC}$ & Urine & 0 & 0 & + & + & $\mathbf{R}$ & 0 \\
\hline $3522-75$ & G-1 & CDC & Urine & 0 & + & + & $(+)$ & $\mathrm{R}$ & + \\
\hline $212-83$ & & $\mathrm{CDC}$ & Stool & 0 & + & + & $(+)$ & $\mathbf{S}$ & + \\
\hline $336-77$ & & $\mathrm{CDC}$ & Ankle & 0 & + & + & 0 & $\mathrm{R}$ & + \\
\hline $1721-75$ & & CDC & Leg wound & 0 & + & + & 0 & $\mathbf{S}$ & + \\
\hline $4920-84$ & & $\mathrm{CDC}$ & Urine & 0 & + & + & $(+)$ & $\mathbf{R}$ & 0 \\
\hline $2248-79$ & & CDC & Stool & 0 & + & + & 0 & $\mathbf{S}$ & + \\
\hline $1629-78$ & & $\mathrm{CDC}$ & Stool & 0 & + & + & 0 & $\mathbf{S}$ & + \\
\hline $4919-84$ & & CDC & Stool & 0 & 0 & + & $(+)$ & $\mathbf{R}$ & + \\
\hline $20980 / 68$ & & Siboni $^{d}$ & Urine & 0 & + & + & $(+)$ & $\mathbf{S}$ & + \\
\hline Perch $325(0$ 4a,4b) & G-2 & Siboni & Unknown & 0 & + & + & $(+)$ & $\mathbf{R}$ & + \\
\hline Perch 524 (O 4a) & & Siboni & Unknown & 0 & + & + & $(+)$ & R & + \\
\hline Perch 587 (O 9) & & Siboni & Unknown & 0 & + & + & $(+)$ & $\mathrm{R}$ & + \\
\hline $44031 / 66$ & & Siboni & Pus & 0 & + & + & $(+)$ & $\mathbf{R}$ & + \\
\hline $46428 / 66$ & & Siboni & Urine & 0 & + & + & $(+)$ & $\mathbf{R}$ & + \\
\hline $47728 / 66$ & & Siboni & Pus & 0 & + & + & $(+)$ & $\mathbf{R}$ & + \\
\hline $16072 / 68$ & & Siboni & Urine & 0 & + & + & + & R & 0 \\
\hline $18635 / 68$ & & Siboni & Abscess on foot & 0 & + & + & $(+)$ & $\mathrm{R}$ & + \\
\hline $18862 \mathrm{II} / 68$ & & Siboni & Clinical isolate & 0 & + & + & $(+)$ & $\mathbf{R}$ & 0 \\
\hline $18866 / 68$ & & Siboni & Pus from leg & 0 & + & + & $(+)$ & $\mathbf{R}$ & + \\
\hline $21239 / 68$ & & Siboni & Cecal abscess & 0 & + & + & $(+)$ & $\mathbf{R}$ & + \\
\hline $21043 / 68$ & & Siboni & Urine & 0 & + & + & $(+)$ & $\mathbf{R}$ & + \\
\hline $19617 / 68$ & & Siboni & Urine & 0 & + & + & $(+)$ & R & + \\
\hline $19504 / 68$ & & Siboni & Peritonitis & 0 & + & + & $(+)$ & $\mathbf{R}$ & + \\
\hline $35234 / 76$ & & Siboni & Urine & 0 & + & + & $(+)$ & $\mathbf{S}$ & + \\
\hline $660 \mathrm{III} / 75$ & & Siboni & Urine & 0 & + & + & + & $\mathbf{R}$ & + \\
\hline $47545 / 66$ & & Siboni & Clinical isolate & 0 & + & + & $(+)$ & R & + \\
\hline $18237 / 68$ & & Siboni & Blood & 0 & + & + & $(+)$ & $\mathbf{R}$ & $t^{c}$ \\
\hline Perch F 5706 (O 15) & & Siboni & Unknown & 0 & + & + & + & R & + \\
\hline Perch F 17925 (O 16) & & Siboni & Unknown & 0 & + & + & $(+)$ & $\mathbf{R}$ & + \\
\hline
\end{tabular}

${ }^{a}$ Lys, lysine; Orn, ornithine; Tre, trehalose; Gly, glycerol; Tet, tetracycline; Mot, motility; S, susceptible; I, intermediately susceptible; R, resistant; +, positive reaction after $48 \mathrm{~h} ; 0$, negative reaction after $48 \mathrm{~h}$. Delayed positive results ( 3 to 7 days) are given in parentheses. SSI, Statens Seruminstitut, Copenhagen, Denmark.

${ }^{b}$ A. von Graevenitz, Department of Medical Microbiology, University of Zürich, Switzerland.

$c$ Swarming.

${ }^{d}$ K. Siboni, Department of Clinical Microbiology, Odense University Hospital, Odense, Denmark. 
TABLE 2. Phenotypic characteristics differentiating M. morganii biogroups ${ }^{a}$

\begin{tabular}{lcccccc}
\hline \multicolumn{1}{c}{ Biogroup } & $\begin{array}{c}\text { No. of } \\
\text { strains }\end{array}$ & Lys & Orn & Tre & $\begin{array}{c}\text { Tet (\% sus- } \\
\text { ceptible) }\end{array}$ & Mot \\
\hline A, ATCC 25830 & 1 & - & + & - & 100 & + \\
B & $22^{b}$ & + & + & - & $100^{c}$ & - \\
C & $14^{b}$ & - & - & - & 14 & $\mathrm{~d}+$ \\
D & 3 & + & - & - & $100^{d}$ & - \\
E & 2 & + & + & + & 0 & + \\
F & 4 & $\mathrm{~d}+$ & - & + & 0 & $\mathrm{~d}+$ \\
$\mathrm{G}^{e}$ & 29 & - & + & + & 21 & + \\
\hline
\end{tabular}

${ }^{a}$ Lys, lysine; Orn, ornithine; Tre, trehalose; Tet, tetracycline; Mot, motility;,$+ \geq 90 \%$ positive within $48 \mathrm{~h} ;-, \leq 10 \%$ positive within $48 \mathrm{~h} ; \mathrm{d}+=50$ to $89 \%$ positive within $48 \mathrm{~h}$.

${ }^{b}$ Data are from reference 9.

c Two strains were intermediately susceptible.

${ }^{d}$ One strain was intermediately susceptible.

$e$ Includes G-1 and G-2.

DNA relatedness studies. Strains were grown to log phase in brain heart infusion broth with shaking at $36 \pm 1^{\circ} \mathrm{C}$ to obtain cells for DNA extraction. The methods used to extract and purify DNA and to determine DNA relatedness between strains have been described elsewhere (2). DNAs were labeled enzymatically in vitro with $\left[{ }^{32} \mathrm{P}\right] \mathrm{dCTP}$, using a nick translation reagent kit (Bethesda Research Laboratories, Inc., Gaithersburg, Md.) as directed by the manufacturer.

Antimicrobial susceptibility testing. All strains in groups E, F, and G-2 were tested against tetracycline and colistin by the agar diffusion method using NeoSensitabs (Rosco Diagnostica, Taastrup, Denmark) and Danish blood agar (Statens Seruminstitut, Copenhagen, Denmark). Strains with a zone diameter of $\geq 28 \mathrm{~mm}$ around the tetracycline tablet were considered tetracycline susceptible (MIC correlate, $\leq 2 \mu \mathrm{g}$ / $\mathrm{ml}$ ), and those with a zone diameter of $\leq 15 \mathrm{~mm}$ were considered tetracycline resistant (MIC correlate, $\geq 32 \mu \mathrm{g}$ / $\mathrm{ml}$ ). Strains with a zone diameter of $\geq 22 \mathrm{~mm}$ around the colistin tablet were considered colistin susceptible (MIC correlate, $\leq 4 \mu \mathrm{g} / \mathrm{ml}$ ), and those with a zone diameter of $\leq 13$ $\mathrm{mm}$ were considered colistin resistant (MIC correlate, $\geq 128$ $\mu \mathrm{g} / \mathrm{ml})$.

\section{RESULTS}

Biochemical tests. $M$. morganii strains were divided into two biogroups on the basis of their abilities to ferment trehalose (Table 2). The trehalose-negative biogroup was subdivided into biogroups $\mathrm{A}, \mathrm{B}, \mathrm{C}$, and $\mathrm{D}$, and the trehalosepositive biogroup was subdivided into biogroups $E, F$, and $G$ on the basis of lysine decarboxylase and ornithine decarboxylase reactions (Table 2). Tetracycline resistance and motility were also of some help in distinguishing biogroups $\mathrm{A}$ through D. Complete biochemical reactions of these seven biogroups are given in Table 3. Biogroup $\mathrm{G}$ strains, although biochemically indistinguishable, are divided into groups G-1 and G-2 because they are distinguishable by DNA hybridization (see below).

DNA relatedness. Initial studies clearly indicated that the strains in biogroup $F$ were distinguishable from those of biogroups $\mathrm{A}, \mathrm{B}$, and $\mathrm{C}$ (Table 4). When labeled DNA from $M$. morganii $25830^{\mathrm{T}}$ (biogroup $\mathrm{A}$ ) was used, biogroup $\mathrm{F}$ showed borderline species-level relatedness to biogroups $\mathrm{A}$, $\mathrm{B}$, and $\mathrm{C}(70 \%$ or greater relatedness and $5 \%$ or less divergence in related sequences is used to define strains in a single species [20]).

Further hybridization studies with biogroups A through $G$ revealed three DNA relatedness groups (Table 5). DNA relatedness group 1 contained biogroups $A$ through $D$. Biogroups $E$ and $F$ and two-thirds of biogroup $G$ strains (biogroup G-2) were in DNA relatedness group 2. The remaining one-third of biogroup $G$ strains (biogroup G-1) constituted DNA relatedness group 3 . The three relatedness groups were interrelated at or just below the species level of relatedness. They were separable by the lower level of intergroup relatedness at both optimal $\left(60^{\circ} \mathrm{C}\right)$ and stringent $\left(75^{\circ} \mathrm{C}\right)$ criteria for DNA reassociation and by their higher divergence in related sequences than was seen with a relatedness group.

Some colonies from strain 13-82 (biogroup F, relatedness group 2) lacked lysine decarboxylase activity [strain 13-82 (c2)], and some colonies swarmed on horse blood agar [strain 13-82 (c3)]. These variants were 94\% related to wild-type strain 13-82 (Table 5). Similar intrastrain variation was not demonstrable with biogroup F strains $8103-85$ and 8104-85.

Trehalose-positive strains 2134-79 and 4919-84 were lysine negative and ornithine negative, placing them midway between biogroup $F$ (lysine variable and ornithine negative) and biogroup $G$ (lysine negative and ornithine positive). Strain 2134-79 was in DNA relatedness group 2 with the biogroup F strains. Strain 4919-84 was in DNA relatedness group 3 .

\section{DISCUSSION}

The type strain of $M$. morganii showed average relatedness to strains from biogroups A through D (DNA relatedness group 1) of $89 \%$ at the optimal DNA reassociation temperature $\left(60^{\circ} \mathrm{C}\right)$, with $1.0 \%$ divergence within related sequences, and $86 \%$ relatedness at the stringent DNA reassociation temperature $\left(75^{\circ} \mathrm{C}\right)$ (Table 5). This high level of relatedness is typical for species whose strains exhibit little heterogeneity. Average relatedness of the $M$. morganii type strain to strains from biogroups E, F, and G-2 (DNA relatedness group 2) was $76 \%$ at $60^{\circ} \mathrm{C}$ with $6 \%$ divergence and $62 \%$ at $75^{\circ} \mathrm{C}$. Relatedness at both optimal and stringent incubation temperatures is at the level of a single species, and the divergence within related sequences is just above the $5 \%$ figure used to define a species (20). Similarly, the $M$. morganii type strain shows average relatedness to biogroup G-1 (DNA relatedness group 3) of $78 \%$ at $60^{\circ} \mathrm{C}$ with $4 \%$ divergence and $67 \%$ at $75^{\circ} \mathrm{C}$.

DNA relatedness groups 2 and 3 also exhibit high intragroup relatedness: $92 \%$ at $60^{\circ} \mathrm{C}$ with $1.5 \%$ divergence and $89 \%$ at $75^{\circ} \mathrm{C}$ for group 2 and $86 \%$ at $60^{\circ} \mathrm{C}$ with $1 \%$ divergence and $84 \%$ at $75^{\circ} \mathrm{C}$ for group 3 (Table 5). Reciprocal relatedness of groups 2 and 3 is at the border of species-level relatedness: 69 and $65 \%$ at $60^{\circ} \mathrm{C}$ with $5 \%$ divergence and 55 to $58 \%$ at $75^{\circ} \mathrm{C}$. Labeled DNAs from both groups 2 and 3 give lower levels of relatedness to DNA relatedness group 1 than was seen in the reciprocal reactions (using labeled DNAs from DNA relatedness group 1). These values, 58 and $50 \%$ (at 60 and $75^{\circ} \mathrm{C}$ for group 2 with group 1) and 65 and $55 \%$ (at 60 and $75^{\circ} \mathrm{C}$ for group 3 with group 1) are below species level, although the percent divergence values (5.0 for group 2 and 3.5 for group 3, respectively, with group 1) are indicative of species-level relatedness and are very similar to those obtained in the reciprocal reactions with labeled DNA from group 1 (6.0 and 4.0, respectively, with groups 2 and 3 ). 
TABLE 3. Phenotypic characteristics of Morganella biogroups

\begin{tabular}{|c|c|c|c|c|c|c|c|c|}
\hline \multirow{2}{*}{ Test $^{a}$} & \multicolumn{8}{|c|}{ Results for biogroup (no. of strains) ${ }^{b}:$} \\
\hline & $\overline{A^{c}(1)}$ & B (15) & $\mathrm{C}(4)$ & $\mathrm{D}(3)$ & $E(2)$ & $F(4)$ & G-1 (9) & $\overline{\text { G-2 }(20)}$ \\
\hline ONPG & 0 & $2(1)$ & $2(1)$ & 0 & 0 & $0(1)$ & 0 & 0 \\
\hline Urea & + & 14 & + & + & + & + & $8(1)$ & + \\
\hline Phenylalanine & + & + & + & + & + & + & 8 & + \\
\hline Lysine (Møllers) & 0 & 14 & 0 & + & + & 3 & 0 & 0 \\
\hline Arginine (Møllers) & 0 & 0 & 0 & 0 & 0 & 0 & 0 & 0 \\
\hline Ornithine (Møllers) & + & 15 & 0 & $\mathbf{0}$ & + & 0 & 8 & + \\
\hline Indole & + & + & + & + & + & 3 & 5 & + \\
\hline Voges-Proskauer & 0 & 0 & 0 & 0 & 0 & 0 & 0 & 0 \\
\hline Malonate & 0 & $1(2)$ & 0 & 0 & 0 & 0 & 0 & 0 \\
\hline Citrate (Simmons) & 0 & 0 & 0 & 0 & 0 & 0 & 0 & $\mathbf{0}$ \\
\hline KCN (growth in) & + & 13 & 3 & + & + & + & 6 & + \\
\hline Gelatin, $22^{\circ} \mathrm{C}$ & 0 & 0 & 0 & 0 & 0 & 0 & 0 & 0 \\
\hline $\mathrm{H}_{2} \mathrm{~S}$ (TSI) & 0 & 0 & 1 & 1 & 0 & 0 & $2(1)$ & 0 \\
\hline Motility, $22^{\circ} \mathrm{C}$ & + & 4 & 2 & 0 & + & 3 & 8 & 18 \\
\hline D-Glucose acid & + & + & + & + & + & + & + & + \\
\hline D-Glucose gas & + & 14 & + & + & + & $3(1)$ & $7(1)$ & + \\
\hline \multicolumn{9}{|l|}{ Acid from } \\
\hline L-Arabinose & 0 & 0 & 0 & 0 & 0 & 0 & 0 & 0 \\
\hline D-Xylose & 0 & 0 & 0 & 0 & 0 & 0 & 0 & 0 \\
\hline L-Rhamnose & 0 & 0 & 0 & 0 & 0 & 0 & 0 & 0 \\
\hline Mannose & + & + & + & + & + & + & $8(1)$ & + \\
\hline Galactose & + & + & + & + & + & + & + & + \\
\hline Sucrose & 0 & 0 & 0 & 0 & 0 & 0 & $1(3)$ & $1(2)$ \\
\hline Lactose & 0 & 0 & 0 & 0 & 0 & 0 & 0 & 0 \\
\hline Maltose & 0 & 0 & 0 & 0 & 0 & 0 & 0 & 0 \\
\hline Cellobiose & 0 & 0 & 0 & 0 & 0 & 0 & 0 & 0 \\
\hline Trehalose & 0 & 0 & 0 & 0 & + & + & + & + \\
\hline Melibiose & 0 & 0 & 0 & 0 & 0 & 0 & 0 & 0 \\
\hline Raffinose & 0 & 0 & 0 & 0 & 0 & 0 & 0 & 0 \\
\hline Adonitol & 0 & 0 & 0 & 0 & 0 & $\mathbf{0}$ & 0 & 0 \\
\hline Dulcitol & 0 & 0 & 0 & 0 & 0 & 0 & 0 & 0 \\
\hline D-Sorbitol & 0 & 0 & 0 & 0 & 0 & 0 & 0 & 0 \\
\hline D-Mannitol & 0 & 0 & 0 & 0 & 0 & 0 & 0 & 0 \\
\hline myo-Inositol & 0 & 0 & 0 & 0 & 0 & 0 & 0 & 0 \\
\hline Salicin & 0 & 0 & 0 & 0 & 0 & 0 & 0 & 0 \\
\hline Glycerol & + & $12(1)$ & $2(2)$ & + & 0 & $1(3)$ & $0(5)$ & $3(17)$ \\
\hline Erythritol & 0 & 0 & 0 & 0 & 0 & 0 & 0 & 0 \\
\hline Alpha-CH $\mathrm{CH}_{3}$-glycoside & 0 & 0 & 0 & 0 & 0 & 0 & 0 & 0 \\
\hline Esculin & 0 & 0 & 0 & 0 & 0 & 0 & 0 & 0 \\
\hline Nitrate reduction & + & + & + & 1 & 1 & + & + & + \\
\hline Oxidase & 0 & 0 & 0 & 0 & 0 & 0 & 0 & 0 \\
\hline Swarming & 0 & 0 & 0 & 0 & 0 & 1 & 0 & 1 \\
\hline Tetracycline & $\mathbf{S}$ & $13 \mathrm{~S} / 2 \mathrm{I}$ & $1 \mathbf{S} / 3 \mathbf{R}$ & $2 S / 11$ & $\mathbf{R}$ & $\mathbf{R}$ & $5 \mathrm{~S} / 4 \mathrm{R}$ & $1 \mathrm{~S} / 19 \mathrm{R}$ \\
\hline Colistin & $\mathbf{R}$ & $\mathbf{R}$ & $\mathbf{R}$ & $\mathbf{R}$ & $\mathbf{R}$ & $\mathbf{R}$ & $\mathbf{R}$ & $\mathbf{R}$ \\
\hline
\end{tabular}

${ }^{a}$ ONPG, $o$-nitrophenyl- $\beta$-D-galactopyranoside; TSI, triple sugar iron.

${ }^{b}+$, all strains positive after $48 \mathrm{~h} ; 0$, all strains negative after 7 days; $S$, susceptible; $R$, resistant; $I$, intermediately susceptible. Results are numbers of strains positive after $48 \mathrm{~h}$ of incubation at $35^{\circ} \mathrm{C}$. Numbers in parentheses are numbers of strains positive after 3 to 7 days of incubation at $35^{\circ} \mathrm{C}$.

c ATCC $25830^{\mathrm{T}}$.

A number of factors indicate that all of the $M$. morganii biogroups are a single species. (i) All strains show specieslevel relatedness to the type strain of $M$. morganii. (ii) DNA relatedness groups 2 and 3 exhibit species-level relatedness. (iii) Divergence within related sequences is similar and at or very close to species level in reciprocal reactions between DNA relatedness groups 1 and 2 and groups 1 and 3 . (iv) In reactions between groups 1 and 2 and groups 1 and 3 , the level of relatedness obtained at the stringent temperature for DNA reassociation drops only slightly compared with that of the optimal temperature for DNA reassociation. This is indicative of strains of the same species.

We therefore conclude that the relatedness values obtained when labeled DNAs from groups 2 and 3 are reacted with group 1 , which are lower than those of the reciprocal reactions, are due to differences in genome size in the strains of these three DNA relatedness groups. Using this reasoning, $76 \%$ of group 1 DNA equals $58 \%$ of group 2 DNA, and $78 \%$ of group 1 DNA equals $65 \%$ of group 3 DNA (Table 5). From these relationships, it follows that $100 \%$ of group 1 DNA is equivalent to $76 \%$ of group 2 DNA and $83 \%$ of group 3 DNA and that $100 \%$ of group 3 DNA is equivalent to $92 \%$ of group 2 DNA. Actually, $71 \%$ of group 3 DNA was equivalent to $69 \%$ of group 2 DNA (Table 5), indicating that $100 \%$ of group 3 DNA is equivalent to $97 \%$ of group 2 DNA.

Subspecies designations are used to group strains of a single species on the basis of one or more differences deemed of value to microbiologists. Criteria used for subspeciation include differences in biochemical characteristics, pathogenicity, host range, and ability to produce an antibi- 
TABLE 4. DNA relatedness of $M$. morganii biogroups A, B, C, and F

\begin{tabular}{|c|c|c|c|c|c|c|}
\hline \multirow{3}{*}{ Source of unlabeled DNA ${ }^{a}$} & \multicolumn{6}{|c|}{$\%$ Relative binding with labeled DNA from: } \\
\hline & \multicolumn{3}{|c|}{ Strain $8103-85$} & \multicolumn{3}{|c|}{ ATCC $25830^{\mathrm{T}}$} \\
\hline & $60^{\circ} \mathrm{C}$ & $\% \mathrm{D}^{b}$ & $75^{\circ} \mathrm{C}$ & $60^{\circ} \mathrm{C}$ & $\% \mathrm{D}$ & $75^{\circ} \mathrm{C}$ \\
\hline \multicolumn{7}{|l|}{ Biogroup } \\
\hline$A(2)$ & $56-62$ & $5.5-6.0$ & $44-45$ & $92-100$ & $0.0-1.0$ & $92-100$ \\
\hline B (10) & $47-69$ & $4.5-6.0$ & $27-51$ & $91-98$ & $1.0-2.0$ & $90-97$ \\
\hline $\mathrm{C}(2)$ & $58-69$ & 5.5 & 48 & 90 & 2.0 & 92 \\
\hline$F(3)$ & $93-100$ & $0.0-1.0$ & $85-100$ & $68-70$ & 5.5 & $51-59$ \\
\hline Proteus spp. (4) & $8-11$ & & & & & \\
\hline Providencia spp. (4) & $4-12$ & & & & & \\
\hline Other Enterobacteriaceae (45) & $4-15$ & & & & & \\
\hline
\end{tabular}

a Numbers in parentheses are numbers of strains (for biogroups) or species (for genera and family) tested.

$b \% \mathrm{D}$, divergence within related sequences (2) calculated to the nearest $0.5 \%$.

otic. Subspecies may also reflect differences in DNA relatedness. It has been recommended that subspecies designations "be used for genetically close organisms that diverge in phenotype" (20), as is the case in Salmonella spp. $(4,10)$.

The DNA relatedness data are compatible with the designation of three subspecies within $M$. morganii: one representing trehalose-negative biogroups $\mathrm{A}$ through $\mathrm{D}$; one representing trehalose-positive biogroups $E, F$, and G-2; and one representing biogroup $\mathrm{G}-1$, which is also trehalose positive. Since the G-1 and G-2 strains are phenotypically indistinguishable, we propose dividing $M$. morganii into two subspecies.

M. morganii subsp. monganii subsp. nov. contains biogroups A, B, C, and D. Biogroup A includes $M$. morganii ATCC $25830^{\mathrm{T}}$. Biogroup $\mathrm{B}$ is equivalent to the lysinepositive biogroup of Hickman et al. (9) and thus includes $M$. morganii biogroup 1 of Farmer et al. (5). Biogroup $\mathrm{C}$ is equivalent to the ornithine-negative biogroups of Hickman et al. (9).

M. morganii subsp. sibonii subsp. nov. contains biogroups $\mathrm{E}, \mathrm{F}$, and G. Trehalose-positive strains belong to $M$. morganii subsp. sibonii. They are usually also characterized by their tetracycline resistance. Siboni found $18(90 \%)$ of 20 trehalose-positive strains to be tetracycline resistant (17). In other studies, frequencies of $35 \%$ (19) and $48 \%$ (7) tetracycline-resistant $M$. morganii were observed, but the proportions of trehalose-positive strains were not noted in these studies. Tetracycline susceptibility in $M$. morganii subsp. sibonii seems to be rare (17). Only $1(6 \%)$ of 16 trehalosepositive strains reported by Senior and Vörös was susceptible to tetracycline (15). There are not many reports on trehalose fermentation in $M$. morganii. Richard observed one of 27 lysine-positive strains to be trehalose positive and tetracycline resistant (14). In other studies, frequencies of trehalose-positive strains of $10 \%$ (5) and $14 \%$ (9) were observed in strains with lysine or ornithine decarboxylase patterns compatible with those of biogroup A. However, no information regarding tetracycline susceptibility is available for these strains. According to the proposed classification, they belong to $M$. morganii subsp. sibonii biogroup G.

Trehalose-negative strains belong to $M$. morganii subsp. morganii. Tetracycline resistance also occurs in this subspecies and has a very high frequency in biogroup C. Hickman et al. found $12(86 \%)$ of 14 ornithine-negative strains to be tetracycline resistant (9). The real frequency of tetracycline resistance in biogroup A is unknown. Siboni found $21(10 \%)$ of 203 trehalose-negative strains to be tetracycline resistant (17).
Biogrouping within the two subspecies is justified by the differences in lysine and ornithine decarboxylase patterns (Table 2). However, the value of lysine as a characteristic suitable for biogrouping $M$. morganii strains was questioned by Cornelis et al. (3), who were able to demonstrate an association between lysine decarboxylation and the presence of a large plasmid in 8 of 14 strains of $M$. morganii. These 8 strains yielded lysine-negative segregants after plasmid curing, and 10 of the 14 strains were able to transfer their lysine-positive characteristic to a recipient $M$. morganii strain. Cornelis et al. used a different lysine decarboxylase test medium than we did but were able to confirm the decarboxylation of lysine by demonstrating cadaverine in the test medium. They argued that lysine could be a plasmidmediated trait in the lysine-positive groups of Hickman et al. (our biogroup B). However, Cornelis et al. did not investigate any of the strains of Hickman et al., and the strains of Cornelis et al. differed from our strains of biogroup $\mathbf{B}$ in several aspects, including motility and inability to ferment glycerol (3).

Even though lysine decarboxylation may be plasmid mediated in some strains, it appears to be a stable characteristic, as reported previously $(3,9)$. In addition, none of the strains in biogroups $E$ and $F$ had lost their abilities to decarboxylate lysine when retested after a 5-year period, although lysine-negative variants segregated in strain 13-82.

Two trehalose-positive strains (2134-79 and 4919-84) that were lysine and ornithine negative belonged to different hybridization groups but could not be separated biochemically. Such strains should be reported as $M$. morganii subsp. sibonii, lysine- and ornithine-negative variants.

Although ATCC $25830^{\mathbf{T}}$ is glycerol positive, glycerol fermentation in biogroup A seems to be rare. The reported frequencies of glycerol fermentation in $M$. morganii have been $2.7 \%$ and $5 \%(5,15)$.

Strains of biogroup G-1 formed DNA relatedness group 3. Phenotypically, these strains are indistinguishable from those of group G-2. For this reason, we do not propose biogroup G-1 as a separate subspecies (20). If useful tests to identify it become available, it will become a third subspecies.

Characteristics useful for differentiating the two $M$. morganii subspecies from Proteus and Providencia species are shown in Table 6. M. morganii subsp. morganii biogroup $C$ can be differentiated from Providencia rustigianii only by the ability of $M$. morganii subsp. monganii to hydrolyze urea.

Sources of $M$. monganii strains are given in Table 1 . No effort was made to obtain additional clinical information. It is 
TABLE 5. DNA relatedness of $M$. morganii biogroups A through G

\begin{tabular}{|c|c|c|c|c|c|c|c|c|c|c|c|c|c|c|c|c|c|c|}
\hline \multirow{3}{*}{$\begin{array}{c}\text { Source of } \\
\text { unlabeled DNA }\end{array}$} & \multicolumn{18}{|c|}{ \% Relative binding with labeled DNA from strain: } \\
\hline & \multicolumn{3}{|c|}{$25830^{\mathrm{T}}$} & & $567-84^{7}$ & & & $3103-85$ & & & $13-82$ & & & $522-75$ & & & $4031 / 66$ & \\
\hline & $60^{\circ} \mathrm{C}$ & $\% \mathrm{D}^{a}$ & $75^{\circ} \mathrm{C}$ & $60^{\circ} \mathrm{C}$ & $\% \mathrm{D}$ & $75^{\circ} \mathrm{C}$ & $60^{\circ} \mathrm{C}$ & $\% \mathrm{D}$ & $75^{\circ} \mathrm{C}$ & $60^{\circ} \mathrm{C}$ & $\% \mathrm{D}$ & $75^{\circ} \mathrm{C}$ & $60^{\circ} \mathrm{C}$ & $\% \mathrm{D}$ & $75^{\circ} \mathrm{C}$ & $60^{\circ} \mathrm{C}$ & $\% \mathrm{D}$ & $75^{\circ} \mathrm{C}$ \\
\hline Biogroup A & & & & & & & & & & & & & & & & & & \\
\hline $25830^{\mathrm{F}}$ & 100 & 0.0 & 100 & 100 & 1.0 & 97 & 62 & 4.0 & 50 & 53 & 6.5 & 45 & 67 & 3.5 & 54 & 77 & 5.0 & 60 \\
\hline $4567-84^{T}$ & 100 & 0.5 & 98 & 100 & 0.0 & 100 & 68 & 4.5 & 56 & 62 & 5.5 & 47 & 65 & 3.5 & 55 & 80 & 5.0 & 65 \\
\hline $1881-73$ & & & & 85 & 1.0 & 86 & & & & 56 & 5.0 & 44 & & & & & & \\
\hline Biogroup B & & & & & & & & & & & & & & & & & & \\
\hline $1939-76$ & & & & 97 & 2.0 & 93 & & & & 57 & 5.5 & 47 & & & & & & \\
\hline $1274-75$ & & & & 95 & 0.5 & 92 & & & & 47 & 5.0 & 47 & 63 & 3.5 & 55 & & & \\
\hline $2325-70$ & & & & 94 & 2.5 & 87 & & & & 61 & 5.5 & 48 & & & & & & \\
\hline $1143-76$ & 100 & 1.0 & 100 & 93 & 0.5 & 95 & 72 & 4.5 & 49 & 57 & 4.5 & 50 & 70 & 3.5 & 60 & 82 & 5.5 & 61 \\
\hline $1072-76$ & & & & 92 & 1.5 & 94 & & & & 57 & 6.0 & 48 & & & & & & \\
\hline $392-75$ & & & & 92 & 0.5 & 88 & & & & 50 & 5.0 & 48 & & & & & & \\
\hline $3528-75$ & & & & 92 & 1.0 & 85 & & & & 52 & 6.0 & 47 & & & & & & \\
\hline $632-76$ & & & & 90 & 1.0 & 85 & & & & 50 & 6.0 & 47 & & & & & & \\
\hline 1753-71 & & & & 87 & 1.5 & 85 & & & & 51 & 6.0 & 41 & & & & & & \\
\hline $4510-74$ & & & & 86 & 1.0 & 80 & & & & 52 & 5.0 & 42 & & & & & & \\
\hline $420-75$ & & & & 85 & 1.0 & 88 & & & & 51 & 5.0 & 47 & 64 & 4.0 & 54 & & & \\
\hline $2432-75$ & & & & 82 & 0.5 & 81 & & & & 49 & 5.0 & 45 & & & & & & \\
\hline $1126-76$ & & & & 81 & 0.5 & 81 & & & & 48 & 5.0 & 46 & & & & & & \\
\hline $3544-74$ & & & & 80 & 0.5 & 71 & & & & 45 & 5.5 & 42 & & & & & & \\
\hline $3566-75$ & & & & 76 & 0.5 & 81 & & & & 45 & 4.5 & 43 & 54 & 3.5 & 50 & & & \\
\hline Biogroup C & & & & & & & & & & & & & & & & & & \\
\hline $1427-73$ & & & & 94 & 0.5 & 88 & & & & 62 & 4.5 & 54 & & & & & & \\
\hline $4564-73$ & & & & 88 & 1.5 & 82 & & & & 67 & 4.0 & 63 & & & & & & \\
\hline $4195-69$ & & & & 87 & 1.5 & 86 & & & & 59 & 5.0 & 55 & & & & & & \\
\hline $3483-75$ & & & & 87 & 1.5 & 76 & & & & 59 & 6.5 & 48 & & & & & & \\
\hline Biogroup D & & & & & & & & & & & & & & & & & & \\
\hline $2866-78$ & & & & 93 & 1.0 & 84 & & & & 64 & 5.5 & 56 & 70 & 3.5 & 60 & & & \\
\hline 728-77 & & & & 87 & 1.0 & 94 & & & & 58 & 3.5 & 53 & & & & & & \\
\hline $1584-68$ & & & & 84 & 1.0 & 90 & & & & 53 & 4.5 & 52 & & & & & & \\
\hline Biogroup E & & & & & & & & & & & & & & & & & & \\
\hline AB 2429 & & & & & & & & & & & & & & & & 91 & 2.5 & 90 \\
\hline AB 2174 & 79 & 5.5 & 61 & & & & 83 & 1.0 & 84 & & & & 72 & 5.0 & 61 & 95 & 2.5 & 90 \\
\hline Biogroup F & & & & & & & & & & & & & & & & & & \\
\hline $13-82$ & 74 & 6.0 & 60 & 76 & 5.5 & 60 & 97 & 0.0 & 99 & 100 & 0.0 & 100 & 75 & 4.5 & 62 & 89 & 1.5 & 86 \\
\hline $13-82$ (c2) (AB 2304) & & & & 72 & 5.5 & 60 & & & & 97 & 0.5 & 92 & & & & & & \\
\hline $13-82$ (c3) (AB 2305) & & & & 77 & 5.5 & 59 & & & & 94 & 1.0 & 100 & & & & & & \\
\hline $8103-85$ (AB 2048) & 77 & 5.5 & 62 & 78 & 6.0 & 67 & 100 & 0.0 & 100 & 98 & 0.5 & 89 & 74 & 5.0 & 60 & 88 & 2.0 & 86 \\
\hline $8104-85$ (AB 2230) & & & & 76 & 6.0 & 62 & & & & 99 & 0.5 & 89 & 69 & 5.5 & 51 & & & \\
\hline $2134-79$ & & & & 73 & 6.0 & 56 & & & & 81 & 2.5 & 74 & & & & & & \\
\hline Biogroup G-1 & & & & & & & & & & & & & & & & & & \\
\hline $3522-75$ & 80 & 4.0 & 65 & 79 & 4.0 & 70 & 61 & 4.0 & 55 & 56 & 5.5 & 53 & 100 & 0.0 & 100 & 77 & 5.0 & 64 \\
\hline $212-83$ & & & & 83 & 3.5 & 77 & & & & 66 & 6.0 & 54 & 89 & 1.0 & 87 & & & \\
\hline $336-77$ & & & & 78 & 3.5 & 67 & & & & 61 & 5.5 & 49 & 83 & 1.0 & 84 & & & \\
\hline $1721-75$ & & & & 74 & 3.5 & 66 & & & & 63 & 5.0 & 49 & 83 & 1.5 & 78 & & & \\
\hline $4920-84$ & & & & & & & & & & & & & 85 & 1.0 & 82 & & & \\
\hline $2248-79$ & 76 & 4.0 & 65 & & & & 70 & 4.0 & 61 & & & & 87 & 1.0 & 90 & 82 & 5.5 & 67 \\
\hline $1629-78$ & & & & & & & & & & & & & 81 & 1.0 & 76 & & & \\
\hline 4919-84 & 77 & 4.0 & 62 & & & & 69 & 4.0 & 60 & & & & 90 & 0.5 & 91 & 78 & 5.0 & 64 \\
\hline $20980 / 68$ & 74 & 5.0 & 65 & & & & 68 & 5.0 & 55 & & & & 88 & 1.0 & 86 & 82 & 5.0 & 65 \\
\hline Biogroup G-2 & & & & & & & & & & & & & & & & & & \\
\hline Perch 325 & & & & & & & & & & & & & & & & 94 & 0.5 & 90 \\
\hline Perch 524 & & & & & & & & & & & & & & & & 95 & 0.5 & 90 \\
\hline Perch 587 & & & & & & & & & & & & & & & & 95 & 1.0 & 86 \\
\hline $44031 / 66$ & 75 & 6.0 & 58 & & & & 84 & 1.5 & 87 & & & & 71 & 5.0 & 59 & 100 & 0.0 & 100 \\
\hline $46428 / 66$ & & & & & & & & & & & & & & & & 96 & 0.5 & 92 \\
\hline $47728 / 66$ & 78 & 5.5 & 60 & & & & 83 & 1.5 & 84 & & & & 72 & 4.5 & 56 & 93 & 0.5 & 93 \\
\hline $16072 / 68$ & & & & & & & & & & & & & & & & 91 & 0.5 & 89 \\
\hline $18635 / 68$ & & & & & & & & & & & & & & & & 93 & 1.5 & 87 \\
\hline $18862 \mathrm{II} / 68$ & & & & & & & & & & & & & & & & 94 & 1.0 & 91 \\
\hline $18866 / 68$ & 74 & 6.0 & 57 & & & & 82 & 1.0 & 83 & & & & 71 & 4.5 & 56 & 92 & 1.5 & 88 \\
\hline $21239 / 68$ & & & & & & & & & & & & & & & & 92 & 2.5 & 90 \\
\hline $21043 / 68$ & 72 & 6.0 & 60 & & & & 79 & 1.5 & 82 & & & & 65 & 5.0 & 53 & 93 & 1.0 & 92 \\
\hline $19617 / 68$ & & & & & & & & & & & & & & & & 92 & 2.0 & 89 \\
\hline $19504 / 68$ & & & & & & & & & & & & & & & & 90 & 2.0 & 88 \\
\hline $35234 / 76$ & & & & & & & & & & & & & & & & 90 & 2.5 & 87 \\
\hline $660 \mathrm{III} / 75$ & & & & & & & & & & & & & & & & 95 & 1.0 & 92 \\
\hline $47545 / 66$ & & & & & & & & & & & & & & & & 98 & 2.0 & 95 \\
\hline $18237 / 68$ & & & & & & & & & & & & & & & & 94 & 0.5 & 95 \\
\hline Perch F 5706 & & & & & & & & & & & & & & & & 89 & 1.0 & 87 \\
\hline Perch F 17925 & & & & & & & & & & & & & & & & 95 & 0.5 & 93 \\
\hline
\end{tabular}

a $\% \mathrm{D}$, divergence within related sequences (2) calculated to the nearest $0.5 \%$. 
TABLE 6. Characteristics useful for differentiating $M$. monganii subspecies and biogroups from Proteus and Providencia species ${ }^{a}$

\begin{tabular}{|c|c|c|c|c|c|c|c|c|c|c|c|c|c|c|c|c|c|}
\hline Strain & $\begin{array}{l}\text { Reference } \\
\text { or source }\end{array}$ & $\mathrm{Ur}$ & Lys & Orn & Ind & Cit & $\mathrm{KCN}$ & $\begin{array}{c}\text { Gel } \\
\left(22^{\circ} \mathrm{C}\right)\end{array}$ & $\begin{array}{l}\mathrm{H}_{2} \mathrm{~S} \\
\text { (TSI) }\end{array}$ & $\begin{array}{l}\text { Mot } \\
\left(22^{\circ} \mathrm{C}\right)\end{array}$ & $\mathrm{X}$ & $\mathrm{Mn}$ & Ma & Tre & Ad & Mt & Er \\
\hline \multicolumn{18}{|c|}{ M. morganii subsp. morganii } \\
\hline Biogroup $A^{b}$ & 11 & + & - & + & + & - & + & - & - & + & - & + & - & - & - & - & - \\
\hline Biogroup B & 9 & + & + & + & + & - & + & - & $d-$ & - & - & + & - & - & - & - & - \\
\hline Biogroup C & 9 & + & - & - & + & - & + & - & $d+$ & $d+$ & - & + & - & - & - & - & - \\
\hline Biogroup D & This study & + & + & - & + & - & + & - & $d-$ & - & - & + & - & - & - & - & - \\
\hline \multicolumn{18}{|l|}{ M. morganii subsp. sibonii } \\
\hline Biogroup $\mathrm{E}$ & This study & + & + & + & + & - & + & - & - & + & - & + & - & + & - & - & - \\
\hline Biogroup F & This study & + & $d+$ & - & $d+$ & - & + & - & - & $d+$ & - & + & - & + & - & - & - \\
\hline Biogroup G & This study & + & - & + & $d+$ & - & $d+$ & - & $d-$ & + & - & + & - & + & - & - & - \\
\hline Proteus mirabilis & 5 & + & - & + & - & $d+$ & + & + & + & + & + & - & - & + & - & - & - \\
\hline Proteus vulgaris & 5 & + & - & - & + & d- & + & + & + & + & + & - & + & d- & - & - & - \\
\hline Proteus penneri & 5 & + & - & - & - & - & + & $d+$ & $d-$ & $d+$ & + & - & + & $d+$ & - & - & - \\
\hline Proteus myxofaciens & 5 & + & - & - & - & $d+$ & + & + & - & + & - & - & + & + & - & - & - \\
\hline Providencia rettgeri & 5 & + & - & - & + & + & + & - & - & + & - & + & - & - & + & + & $d+$ \\
\hline Providencia stuartii & 5 & $d-$ & - & - & + & + & + & - & - & $d+$ & - & + & - & + & - & - & - \\
\hline Providencia alcalifaciens & 5 & - & - & - & + & + & + & - & - & + & - & + & - & - & + & - & - \\
\hline Providencia rustigianii & 5 & - & - & - & + & $d-$ & + & - & - & d- & - & + & - & - & - & - & - \\
\hline Providencia heimbachae & 12 & - & - & - & - & - & - & - & - & $d-$ & - & + & $d+$ & - & + & - & - \\
\hline
\end{tabular}

a Ur, urea; Lys, lysine decarboxylase; Orn, ornithine decarboxylase; Ind, indole; Cit, citrate; KCN, growth in KCN; Gel, gelatin; TSI, triple sugar iron; Mot, motility; X, xylose; Mn, Mannose; Ma, Maltose; Tre, trehalose; Ad, adonitol; Mt, mannitol; Er, erythritol; +, $\geq 90 \%$ positive within 48 h; -, $\leq 10 \%$ positive within $48 \mathrm{~h}$; d+, 50 to $89 \%$ positive within $48 \mathrm{~h}$; d-, 11 to $49 \%$ positive within $48 \mathrm{~h}$.

${ }^{b} M$. morganii ATCC $25830^{\mathrm{T}}$.

premature to speculate on any differential clinical significance of the subspecies or the biogroups within them. Nonetheless, some differences in the sources of isolation of the few strains in this study are worth noting. Twenty-five $M$. morganii subsp. morganii strains were mostly isolated from stool $(32 \%)$, wounds $(28 \%)$, sputum (20\%), and urine (12\%). Seventeen $M$. morganii subsp. sibonii strains from biogroups $E, F$, and G-2 were isolated predominantly from wounds and urine ( $41 \%$ each), with only a single isolate from stool $(6 \%)$. The nine biogroup G-1 strains (DNA relatedness group 3) in $M$. morganii subsp. sibonii were isolated from stool $(44 \%)$, urine $(33 \%)$, and wounds $(22 \%)$. The only isolate from blood in this study was a biogroup G-2 strain.

Description of Morganella morganii subsp. morganii subsp. nov. (mor.ga'ni.i. M. L. gen. n. morganii, of Morgan; named after $H$. de $R$. Morgan, a British bacteriologist who first studied the organism).

The description is based on the strains belonging to biogroups A, B, C, and D of the present study. Characteristics are as given previously for the genus (13), with the following exceptions. Members of biogroup $B$ are lysine positive and mostly nonmotile. Members of biogroup $\mathrm{C}$ are ornithine negative. Members of biogroup D are lysine positive and ornithine negative. Biochemical characteristics for biogroup A are as given previously for ATCC $25830^{\mathrm{T}}$ (11). Complete biochemical characteristics of biogroups A, B, C, and $\mathrm{D}$ are listed in Tables 2 and 3 . Acid not produced from trehalose. Isolated from human clinical specimens (stool, wound, sputum, eye, bile, gastric ulcer, urine). The type strain is ATCC 25830.

Description of Morganella morganii subsp. sibonii subsp. nov. (si.bo'ni.i. M. L. gen. n. sibonii, of Siboni; named after Knud Siboni, a Danish microbiologist who first recognized trehalose-fermenting $M$. monganii as a separate group).

The description is based on studies of 35 strains (groups $\mathrm{E}$, F, G-1, and G-2 of the present study). Characteristics are as given previously for the genus (13) with the following excep- tions. Acid is produced from trehalose, and two strains are swarming. Members of biogroup $\mathrm{E}$ are lysine positive and ornithine positive. Members of biogroup F are lysine variable and ornithine negative. Members of biogroup $G$ are lysine negative and ornithine positive. Complete biochemical reactions are listed in Tables 2 and 3. Most strains are tetracycline resistant. All strains are colistin resistant. Isolated from human clinical specimens (sputum, urine, stool, wound). The type strain is $8103-85$ (=ATCC 49948).

Description of the type strain. The type strain of $M$. morganii subsp. sibonii is $8103-85\left(=\mathrm{AB} 2048^{\mathrm{T}}\right.$, $=\mathrm{ATCC}$ 49948). This strain was isolated from human sputum. Colonies on nutrient agar are circular, convex, and smooth with entire edges. Colonies are 1 to $2 \mathrm{~mm}$ in diameter, greyish, and opaque after $24 \mathrm{~h}$ at $35^{\circ} \mathrm{C}$. Good growth occurs at $22^{\circ} \mathrm{C}$. Motile. Urease, phenylalanine, and indole positive. Lysine decarboxylase positive, ornithine and arginine decarboxylase negative. Voges-Proskauer and malonate negative. No growth occurs in citrate. KCN resistant. Gelatin not liquefied. $\mathrm{H}_{2} \mathrm{~S}$ negative. $\beta$-Galactosidase and $\beta$-glucuronidase negative. Acid and gas produced from glucose. Acid produced from mannose, galactose, and trehalose. Acid not produced from arabinose, xylose, rhamnose, sucrose, lactose, maltose, cellobiose, melibiose, raffinose, adonitol, dulcitol, sorbitol, mannitol, inositol, salicin, erythritol, glycerol, and esculin. $\alpha$-Methyl glycoside negative. Nitrate reductase positive. Oxidase negative. Tetracycline and colistin resistant.

\section{REFERENCES}

1. Brenner, D. J., J. J. Farmer III, G. R. Fanning, A. G. Steigerwalt, P. Klykken, H. G. Wathen, F. W. Hickman, and W. H. Ewing. 1978. Deoxyribonucleic acid relatedness of Proteus and Providencia species. Int. J. Syst. Bacteriol. 28:269-282.

2. Brenner, D. J., A. C. McWhorter, J. K. Leete Knutson, and A. G. Steigerwalt. 1982. Escherichia vulneris: a new species of Enterobacteriaceae associated with human wounds. J. Clin. Microbiol. 15:1133-1140. 
3. Cornelis, G., M. van Bouchaute, and G. Wauters. 1981. Plasmidencoded lysine decarboxylation in Proteus morganii. J. Clin. Microbiol. 14:365-369.

4. Crosa, J. G., D. J. Brenner, W. H. Ewing, and S. Falkow. 1973. Molecular relationships among the Salmonellae. J. Bacteriol. 115:307-315.

5. Farmer, J. J., III, B. R. Davis, F. W. Hickman-Brenner, A. McWhorter, G. P. Huntley-Carter, M. A. Asbury, C. Riddle, H. G. Wathen-Grady, C. Elias, G. R. Fanning, A. G. Steigerwalt, C. M. O'Hara, G. K. Morris, P. B. Smith, and D. J. Brenner. 1985. Biochemical identification of new species and biogroups of Enterobacteriaceae isolated from clinical specimens. J. Clin. Microbiol. 21:46-76.

6. Fulton, M. 1943. The identity of Bacterium columbensis Castellani. J. Bacteriol. 46:79-82.

7. Hedges, R. W., N. Datta, J. N. Coetzee, and S. Dennison. 1973. $\mathrm{R}$ factors from Proteus morganii. J. Gen. Microbiol. 77:249 259.

8. Hickman, F. W., and J. J. Farmer III. 1978. Salmonella typhi: identification, antibiograms, serology, and bacteriophage typing. Am. J. Med. Technol. 44:1149-1159.

9. Hickman, F. W., J. J. Farmer III, A. G. Steigerwalt, and D. J. Brenner. 1980. Unusual groups of Morganella ("Proteus") monganii isolated from clinical specimens: lysine-positive and ornithine-negative biogroups. J. Clin. Microbiol. 12:88-94.

10. Le Minor, L., M. Véron, and M. Popoff. 1982. Taxonomie des Salmonella. Ann. Microbiol. (Inst. Pasteur) 133B:223-243.

11. Lessel, E. F. 1971. Status of the name Proteus morganii and designation of the neotype strain. Int. J. Syst. Bacteriol. 21:5557.

12. Müller, H. E., C. M. O'Hara, G. R. Fanning, F. W. HickmanBrenner, J. M. Swenson, and D. J. Brenner. 1986. Providencia heimbachae, a new species of Enterobacteriaceae isolated from animals. Int. J. Syst. Bacteriol. 36:252-256.

13. Penner, J. L. 1984. Genus XIII Morganella Fulton 1943, p. 497. In N. R. Krieg and J. G. Holt (ed.), Bergey's manual of systematic bacteriology, vol. 1 . The Williams \& Wilkins Co., Baltimore.

14. Richard, C. 1979. Entérobactéries inhabituelles. Bull. Inst. Pasteur 77:83-98.

15. Senior, B. W., and S. Vörös. 1990. Protein profile typing-a new method of typing Monganella morganii strains. J. Med. Microbiol. 33:259-264

16. Siboni, K. 1976. Correlation of the characters fermentation of trehalose, non-transmissible resistance to tetracycline, and flagellar wavelength in Proteus morganii. Acta Pathol. Microbiol. Scand. Sect. B 84:421-427.

17. Siboni, K. 1980. The occurrence of the trehalose fermenting, tetracycline and polymyxin resistant phenotype among the Enterobacteriaceae. Acta Pathol. Microbiol. Scand. Sect. B 88:185-188.

18. Skerman, V. B. D., V. McGowan, and P. H. A. Sneath (ed.). 1980. Approved lists of bacterial names. Int. J. Syst. Bacteriol. 30:225-420.

19. von Graevenitz, A., and M. Nourbakhsh. 1972. Antimicrobial resistance of the genera Proteus, Providencia and Serratia with special reference to multiple resistance patterns. Med. Microbiol. Immunol. 157:142-148.

20. Wayne, L. G., D. J. Brenner, R. R. Colwell, P. A. D. Grimont, O. Kandler, M. I. Krichevsky, L. H. Moore, W. E. C. Moore, R. G. E. Murray, E. Stackebrandt, M. P. Starr, and H. G. Trüper. 1987. Report of the ad hoc committee on reconciliation of approaches to bacterial systematics. Int. J. Syst. Bacteriol. 37:463-464. 